\title{
EFFECT OF DIFFERENT POTASSIUM FERTILIZER RATES AND FOLIAR APPLICATION WITH SOME SOURCES OF POTASSIUM ON GROWTH, YIELD AND QUALITY OF CARROT PLANTS (Daucus carota L.) Abou El-Nasr, M. E. and E. A. Ibrahim Veget. Res. Dept., Hort. Res. Inst., Agric. Res. Center, Giza, Egypt.
}

\begin{abstract}
Two field experiments were carried out at Barramoon experimental farm, Hort. Res., Institute, Dakahlia Governorate, Egypt, during the two winter seasons of $2007 / 2008$ and $2008 / 2009$ to study the effect of different rates of potassium fertilization $(0,25,50$ and $75 \mathrm{~kg} \mathrm{~K} 2 \mathrm{O} / \mathrm{fad}$.) as potassium sulfate in addition to foliar application by water (control), liquid potassium $(3 \mathrm{ml} / \mathrm{L})$, potassium borate citrate (3 $\mathrm{ml} / \mathrm{L})$ and NPK- humate $(3 \mathrm{ml} / \mathrm{L})$ and their interaction on production and quality of carrot cv. "Chantenay Red Core". Potassium foliar applications were made 3 times at 20 days intervals with the same doses during the growing period (20, 40 and 60 days after sowing). The highest potassium fertilization rate $(75 \mathrm{~kg} \mathrm{~K} 2 \mathrm{O} / \mathrm{fad}$.) gave the tallest shoot, the highest number of leaves per plant and the highest fresh weight of shoots as well as the highest total yield per fadden in both seasons. Also, the obtained results reported that the root measurements expressed as (root length, root diameter root weight, TSS and carotenoids content, as well as leaves chemical composition ( $N$, $\mathrm{P}$ and $\mathrm{K}$ concentrations) were increased with increasing potassium fertilization rate in both seasons. On the other hand, spraying carrot plants with potassium humate at a rate of $3 \mathrm{ml} / \mathrm{L}$ markedly increased vegetative growth, yield, root quality and chemical composition in both seasons. The favorable effects of the potassium on the growth, total yield and root parameters were obtained when carrot plants fertilized with $75 \mathrm{~kg}$ $\mathrm{K}_{2} \mathrm{O} / \mathrm{fad}$. as potassium sulfate plus foliar application of potassium humate $(3 \mathrm{ml} / \mathrm{L})$ followed statistically by $75 \mathrm{~kg} \mathrm{~K} \mathrm{~K}_{2} \mathrm{O} / \mathrm{fad}$. with foliar application of potassium borate citrate $(3 \mathrm{ml} / \mathrm{L})$ in both seasons.

Keywords: Daucus carota, Carrot, potassium, fertilizer, foliar, humate, citrate.
\end{abstract}

\section{INTRODUCTION}

Carrot (Daucus carota L.) is an important vegetable in Egypt. The fleshy roots are eaten as raw in salads, boiled or steamed in vegetable dishes and also used with other vegetables in the preparation of soup and its increasing importance as human food. It covers a production area of 13,651 fed. in year 2010 that yielded 175,923 tons according to Ministry of Agriculture Statistics.

Carrot is a potassium-demanding plant (Kadar, 2008). Potassium has a crucial role in the energy status of the plant, translocation and storage of assimilates and maintenance of tissue water relation. Also potassium plays a key role of crop quality. It stimulates root growth. It is necessary for the translocation of sugars and formation of carbohydrates. Potassium also provides resistance against pest and diseases and drought as well as frost stresses. It is a highly mobile element in the plant and has a specific phenomenon, it is called luxury consumption (Marschner, 1995). 
Increasing productivity of carrot with high quality is an important target by the carrot growers. Potassium application is very important for carrot plants. Hochmuth et al. (2006) indicated that potassium is required for successful carrot production. Moreover, several studies revealed the importance of potassium to achieve high carrot yield (Balooch et al., 1993; Ali et al., 2003; Anjaiah and Padmaja, 2006; Bartaseviciene and Pekarskas, 2007) and quality of roots (Balooch et al., 1993; Sharangi and Paria, 1995; Sharangi and Paria, 1997; Lyngdoh, 2001; Ali et al., 2003). Carrot root yield and carotene content increased progressively and significantly with the increased application of potassium (Ali et al., 2003).

Nowadays, potassium fertilization became an important factor for carrot production under Egyption soils. However, farmers minimizing the used amount to the minimum dose or ignored using it because chemical potassium fertilizer became a high expensive fertilizer in Egypt In addition to use any other newly and cheapest potassium sources through foliar application to overcome such problem and to maximize their net return to cover the additional cost of this $\mathrm{K}$ fertilizer source.

Foliar fertilization is more economical than root fertilization due to the efficiency and lower cost. The foliar method of fertilizer application is usually preferred because very small amounts of fertilizers are applied per hectare. It also reduces the number of passes of the applicant, thereby reducing problem of soil compactness. Foliar application is also less likely to result in ground water pollution. Foliar application of potassium increased the growth and yield of carrot plants (Subrahmanyam and Raju, 2000; El-Tohamy et al., 2011).

Potassium in organic chelated form (potassium borate citrate and NPKHumate) can be used as a inexpensive source for potassium and it could be used as foliar application. It was reported by many researchers that they increased the plant growth, nutrient uptake and plant yield as well as quality (Fathy and El-Hamady, 2007 on cowpea; Karakurt et al., 2009 on pepper).

The main objective of this study was to investigate the effect of different potassium fertilization rates in addition to foliar spray of liquid potassium, potassium borate citrate and NPK- humate on the vegetative growth parameters, total roots yield and its physical and chemical constituents of carrot plants.

\section{MATERIALS AND METHODS}

Carrot seeds cv. "Chantenay Red Core" were sown at Barramoon experimental farm, Hort. Res., Institute, Dakahlia Governorate, Egypt, on 4 and 3 September in winter seasons of 2007/2008 and 2008/2009, respectively. The soil is clay loam in texture. Some physical and chemical properties of the studied soil are shown in Table (1) with reference to Page (1982).

A split plot design in a randomized complete block with three replicates was used. The main plots were assigned to four potassium fertilization rates $\left(0,25,50\right.$ and $75 \mathrm{~kg} \mathrm{~K} \mathrm{O}_{2} \mathrm{O} / \mathrm{fad}$.). The subplots were devoted to the four foliar 
applications (liquid potassium, potassium borate citrate, NPK- Humate and control). The sub plot area was $10.5 \mathrm{~m}^{2}$ ( $3 \mathrm{~m}$ in width $\times 3.5 \mathrm{~m}$ in length) included 5 ridges, $60 \mathrm{~cm}$ apart. Each treatment was separated by two guard ridges.

Table (1): Some physical and chemical properties of the experimental soil surface layer (at the depth of $0-30$ ) before planting in 2007/08 and 2008/09 seasons

\begin{tabular}{|c|c|c|c|c|c|}
\hline \multirow{2}{*}{ Properties } & \multicolumn{2}{|c|}{ Values } & \multirow{2}{*}{ Properties } & \multicolumn{2}{|c|}{ Values } \\
\hline & $2007 / 08$ & $2008 / 09$ & & $2007 / 08$ & $2008 / 09$ \\
\hline Sand (\%) & 27.6 & 27.5 & $\mathrm{pH}^{*}$ & 7.6 & 7.7 \\
\hline Silt (\%) & 32.1 & 31.9 & $E C\left(\mathrm{dSm}^{-1}\right)^{* \star}$ & 0.7 & 0.7 \\
\hline Clay (\%) & 40.3 & 40.6 & Total N (\%) & 0.13 & 0.15 \\
\hline Texture class & Clay-loam & Clay-loam & Available P (ppm) & 11.4 & 11.6 \\
\hline $\begin{array}{l}\mathrm{CaCO}_{3} \\
\mathrm{OM}(\%)\end{array}$ & $\begin{array}{l}3.3 \\
2.0\end{array}$ & $\begin{array}{l}3.6 \\
2.2\end{array}$ & Exchangeable $\mathrm{K}$ (ppm) & 293 & 287 \\
\hline
\end{tabular}

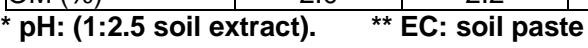

Potassium treatments in the form of potassium sulfate $\left(48 \% \mathrm{~K}_{2} \mathrm{O}\right)$, ammonium sulfate $(20.6 \% \mathrm{~N})$ at rate of $60 \mathrm{~kg} \mathrm{~N} / \mathrm{fed}$. and calcium superphosphate $\left(16 \% \mathrm{P}_{2} \mathrm{O}_{5}\right)$ at rate of $40 \mathrm{~kg} \mathrm{P}_{2} \mathrm{O}_{5} / \mathrm{fed}$. were divided in two equal portions. The first portion of calcium super phosphate was broadcasted during seed bed preparation and the second portion was added with the first portion of $\mathrm{N}$ and $\mathrm{K}$ fertilizers which was added at the fourth week after seed sowing, and the second portion of $\mathrm{N}$ and $\mathrm{K}$ fertilizers was added at the eighth week after seeds sowing. Other agricultural practices were conducted according to Ministry of Agriculture recommendations.

Regarding foliar spray treatments, they have been applied as follows:

1- Liquid potassium $\left(37.5 \% \mathrm{~K}_{2} \mathrm{O}\right.$, Kafr El Zayat Pesticides \& Chemicals Co., Egypt), applied at concentration of $3 \mathrm{ml} / \mathrm{L}$.

2- Potassium borate citrate $\left(35 \% \mathrm{~K}_{2} \mathrm{O}, 5 \% \mathrm{~B}\right)$ formulation of Hort. Res. Inst., Egypt, applied at concentration of $3 \mathrm{ml} / \mathrm{L}$.

3- NPK- humate: $10 \%$ humic acids + $8 \% \mathrm{~N}+8 \% \mathrm{P}_{2} \mathrm{O}_{5}+8 \% \mathrm{~K}_{2} \mathrm{O}$ registered with NO. 5709, Hort. Res. Inst., Egypt, applied at concentration of $3 \mathrm{ml} / \mathrm{L}$.

4- Control, only sprayed with tap water.

These treatments were sprayed three times (at 20 days after sowing and again every 20 days). Bio-film as a wetting agent was applied at $0.5 \mathrm{ml} /$ liter of solution. The plants were sprayed until dropp-off by using a hand-sprayer.

Seeds were drilled on both sides of ridges. After complete emergence the plants were thinned to have a uniform spacing of $3-5 \mathrm{~cm}$. All agricultural practices were carried out according to the recommendations of Ministry of Agriculture.

At 80 days after sowing, samples of 10 plants from each plot were taken to determine N, P and $\mathrm{K}$ concentrations in shoots. Shoot samples were separated and oven dried at $70{ }^{\circ} \mathrm{C}$ for $72 \mathrm{~h}$ to constant weight, then fine grounded and wet digested. Total nitrogen was determined with microkjeldahl method according to Chapman and Pratt (1961). Phosphorus was determined colorimetrically using the chlorostannous reduced molybdophosporic blue color method as described by Jackson (1973). 
Potassium was determined using a flame photometer as described by Jackson (1973).

At the harvesting time (120 days from sowing), the yield of roots as ton/fed. was calculated. In the same time, samples of 10 plants from each experimental plot were taken to record vegetative growth parameters (shoot height, number of leaves per plant and shoot fresh weight), yield components (root length, root diameter and root weight), TSS (measured by hand Refractometer) and carotenoids content in root according to methods mentioned by Umiel and Gabelmoii (1971).

The obtained data were statistically analyzed and means separation were done using LSD test according to the method described by Snedecor and Cochran (1982).

\section{RESULTS AND DISCUSSION}

\section{Vegetative growth parameters:}

Data presented in Table (2) show that potassium as soil application had a significant effect on vegetative growth parameters, i.e., shoot height, number of leaves per plant and shoot fresh weight. The highest vegetative growth parameters were recorded with soil application of $75 \mathrm{~kg} \mathrm{~K} 2 \mathrm{O} / \mathrm{fad}$.. These findings were true in both seasons. These results may be due to the role of potassium element in metabolism and many processes needed to sustain and promote plant vegetative growth and development. Moreover, $\mathrm{K}$ plays a major role in many physiological and biochemical processes such as cell division and elongation and metabolism of carbohydrates and protein compounds (Marschner, 1995). The obtained results are in a good accordance with those recorded by EL-Bassiouny et al. (2003) and Hossain et al. (2009) who found that increasing potassium fertilizer levels increased shoot height, number of leaves per plant and shoot fresh weight.

Regarding potassium foliar application, treatments had a significant effect on growth parameters (shoot height, number of leaves per plant and shoot fresh weight) in both seasons (Table, 2). Spraying carrot plants with NPKhumate produced the highest values of growth parameters followed by spraying plants with potassium borate citrate and liquid potassium in both seasons; while control treatment (without potassium foliar application) gave the lowest values of these characters in both seasons. The superiority of plant growth with the addition of NPK-humate might be attributed to that, the organic - mineral complex of NPK-humate is greatly induced high balanced $\mathrm{N}, \mathrm{P}$ and $\mathrm{K}$ concentration within carrot leaves (Table, 4), besides the role of humic acids in protein synthesis, nutrients translocation, antioxidantal enzymes, root proliferation and foliar growth (Chen and Avaid., 1990; Chen et al., 2004). The most growth encourages effect of potassium borate citrate may be due to that this formulation contain $\mathrm{K}$ and $\mathrm{B}$ of the similar and harmonic synergetic action, complexes with organic moiety of citrate, ensuring potent $\mathrm{K}$ and $\mathrm{B}$ nutrition for more enhancement of carbohydrates, proteins, enzymes and energy synthesis (Marschner, 1995). These results 
are in agreement with those of Subrahmanyam and Raju (2000), Zhang et al. (2006) and El-Tohamy et al. (2011).

Table (2): Effect of different potassium levels, potassium foliar application and their interaction on vegetative growth parameters of carrot plant in seasons of 2007/08 and 2008/09.

\begin{tabular}{|c|c|c|c|c|c|c|c|}
\hline & \multirow{2}{*}{ Treatments } & \multicolumn{2}{|c|}{$\begin{array}{c}\text { Shoot height } \\
(\mathrm{cm})\end{array}$} & \multicolumn{2}{|c|}{$\begin{array}{c}\text { Number of leaves / } \\
\text { plant }\end{array}$} & \multicolumn{2}{|c|}{$\begin{array}{c}\text { Shoot fresh weight/ } \\
\text { plant }(\mathrm{g})\end{array}$} \\
\hline & & $2007 / 08$ & $2008 / 09$ & $2007 / 08$ & $2008 / 09$ & $2007 / 08$ & $2008 / 09$ \\
\hline \multicolumn{8}{|c|}{ Effect of potassium fertilization rates (kg K2O/fed.) } \\
\hline & 0 & 46.9 & 47.0 & 9.2 & 9.0 & 31.1 & 30.4 \\
\hline & 25 & 55.4 & 56.0 & 12.2 & 12.0 & 43.4 & 42.3 \\
\hline & 50 & 62.9 & 63.1 & 14.8 & 14.8 & 54.1 & 52.6 \\
\hline & 75 & 68.3 & 66.3 & 16.6 & 16.4 & 55.2 & 53.7 \\
\hline & LSD (5\%) & 1.2 & 1.1 & 0.5 & 0.5 & 1.2 & 1.3 \\
\hline \multicolumn{8}{|c|}{ Effect of potassium foliar application } \\
\hline & Control & 54.6 & 54.8 & 12.2 & 12.1 & 42.5 & 41.4 \\
\hline & Liquid K & 57.6 & 57.1 & 12.9 & 12.8 & 45.1 & 44.0 \\
\hline & $\mathrm{K}$ borate citrate & 60.1 & 59.4 & 13.5 & 13.3 & 47.2 & 45.9 \\
\hline & NPK- humate & 61.2 & 61.1 & 14.2 & 14.0 & 49.0 & 47.7 \\
\hline & LSD (5\%) & 1.4 & 1.6 & 0.6 & 0.6 & 1.6 & 1.6 \\
\hline \multicolumn{8}{|c|}{ Effect of the interaction } \\
\hline \multirow{4}{*}{0} & Control & 42.2 & 43.6 & 8.1 & 8.0 & 26.4 & 25.9 \\
\hline & Liquid K & 45.6 & 46.4 & 9.0 & 8.9 & 29.6 & 29.0 \\
\hline & $\mathrm{K}$ borate citrate & 49.8 & 48.02 & 9.5 & 9.3 & 32.7 & 31.9 \\
\hline & NPK- humate & 49.9 & 50.06 & 10.0 & 9.7 & 35.7 & 34.7 \\
\hline \multirow{4}{*}{25} & Control & 51.5 & 52.7 & 10.8 & 10.6 & 39.2 & 38.1 \\
\hline & Liquid K & 54.5 & 55.2 & 11.7 & 11.6 & 42.1 & 41.0 \\
\hline & $\mathrm{K}$ borate citrate & 56.8 & 57.1 & 12.3 & 12.1 & 45.0 & 43.8 \\
\hline & NPK- humate & 58.9 & 59.0 & 13.9 & 13.7 & 47.3 & 46.2 \\
\hline \multirow{4}{*}{50} & Control & 59.7 & 59.3 & 13.8 & 13.8 & 50.6 & 49.3 \\
\hline & Liquid K & 62.5 & 61.4 & 14.6 & 14.5 & 53.9 & 52.5 \\
\hline & $\mathrm{K}$ borate citrate & 64.4 & 65.3 & 15.2 & 15.3 & 55.3 & 53.8 \\
\hline & NPK- humate & 65.1 & 66.2 & 15.7 & 15.5 & 56.4 & 54.9 \\
\hline \multirow{5}{*}{75} & Control & 65.1 & 63.4 & 16.1 & 15.9 & 53.7 & 52.2 \\
\hline & Liquid K & 67.8 & 65.5 & 16.4 & 16.3 & 54.7 & 53.4 \\
\hline & $\mathrm{K}$ borate citrate & 69.2 & 67.3 & 16.8 & 16.6 & 55.8 & 54.1 \\
\hline & NPK- humate & 71.0 & 69.1 & 17.1 & 16.9 & 56.6 & 55.0 \\
\hline & LSD (5\%) & 1.8 & 2.3 & 0.8 & 0.5 & 2.5 & 2.2 \\
\hline
\end{tabular}

Regarding the interaction effect, there were significant effects on growth parameters in both seasons (Table, 2). The highest values of shoot height, number of leaves per plant and shoot fresh weight were recorded by using 75 $\mathrm{kg} \mathrm{K}_{2} \mathrm{O} / \mathrm{fad}$. With foliar application of NPK -humate followed by using $75 \mathrm{~kg}$ $\mathrm{K}_{2} \mathrm{O} / \mathrm{fad}$. with foliar application of potassium borate citrate. These findings were true in both seasons. Similar results were obtained by El-Bassiony (2006) and El-Bassiony et al. (2010) who found that the highest vegetative parameters of onion and sweet pepper plants were recorded when used potassium in the highest level as soil application with foliar application of $\mathrm{K}$ humate or potassium oxide.

\section{Yield and its components:}

Data presented in Table (3) indicate that carrot yield and its components (root length, root diameter and root weight) were significantly increased by 
increasing $\mathrm{K}$ fertilizer up to $75 \mathrm{~kg} \mathrm{~K} 2 \mathrm{O} / \mathrm{fad}$. in both seasons. The increases in these traits may be due to the superiority of vegetative growth parameters (Table, 3) and N, P, and K content (Table, 4) of the treated plants, which could be attributed to the stimulatory effect of $\mathrm{K}$ on rate of photosynthesis, as well as, transport of the photosynthetic product from the leaves to the storage root (Marschner, 1995). These results are in harmony with those obtained by Balooch et al. (1993), Shibairo et al. (1998), Ali et al. (2003), EL-Bassiouny et al. (2003), Anjaiah and Padmaja (2006), Bartaseviciene, and Pekarskas (2007) and Hossain et al. (2009).

Table (3): Effect of different potassium levels, potassium foliar application and their interaction on carrot yield and its components in seasons of 2007/08 and 2008/09.

\begin{tabular}{|c|c|c|c|c|c|c|c|c|c|}
\hline & \multirow{2}{*}{ Treatments } & \multicolumn{2}{|c|}{$\begin{array}{l}\text { Root length } \\
\text { (cm) }\end{array}$} & \multicolumn{2}{|c|}{$\begin{array}{l}\text { Root diameter } \\
\text { (cm) }\end{array}$} & \multicolumn{2}{|c|}{$\begin{array}{l}\text { Root weight } \\
\text { (g) }\end{array}$} & \multicolumn{2}{|c|}{$\begin{array}{c}\text { Roots yield } \\
\text { (ton/fed.) }\end{array}$} \\
\hline & & $\begin{array}{c}2007 \\
108\end{array}$ & $\begin{array}{c}2008 \\
109\end{array}$ & $\begin{array}{c}2007 \\
/ 08\end{array}$ & $\begin{array}{c}2008 \\
/ 09\end{array}$ & $\begin{array}{c}2007 \\
/ 08\end{array}$ & $\begin{array}{c}2008 \\
/ 09\end{array}$ & $\begin{array}{c}2007 \\
/ 08\end{array}$ & $\begin{array}{c}2008 \\
109\end{array}$ \\
\hline \multicolumn{10}{|c|}{ Effect of potassium fertilization rates $\left(\mathrm{kg} \mathrm{K}_{2} \mathrm{O} / \mathrm{fed}\right.$.) } \\
\hline & 0 & 10.9 & 10.6 & 2.2 & 2.2 & 57.4 & 57.1 & 13.32 & 13.52 \\
\hline & 25 & 13.2 & 12.9 & 2.8 & 2.8 & 68.1 & 67.7 & 14.96 & 14.90 \\
\hline & 50 & 15.3 & 14.9 & 3.3 & 3.3 & 75.5 & 75.0 & 16.19 & 16.13 \\
\hline & 75 & 16.5 & 16.0 & 3.8 & 3.7 & 82.7 & 82.6 & 17.03 & 16.99 \\
\hline & LSD (5\%) & 0.5 & 0.4 & 0.2 & 0.2 & 3.2 & 3.7 & 0.33 & 0.31 \\
\hline \multicolumn{10}{|c|}{ Effect of potassium foliar application } \\
\hline Cont & trol & 12.7 & 12.3 & 2.6 & 2.6 & 60.7 & 60.6 & 14.47 & 14.42 \\
\hline Liqui & id $\mathrm{K}$ & 13.7 & 13.3 & 2.9 & 2.9 & 68.0 & 67.7 & 15.11 & 15.31 \\
\hline $\mathrm{K}$ bo & rate citrate & 14.4 & 14.0 & 3.2 & 3.1 & 74.4 & 74.0 & 15.66 & 15.62 \\
\hline NPK & - humate & 15.2 & 14.7 & 3.4 & 3.3 & 80.6 & 80.2 & 16.25 & 16.20 \\
\hline & LSD (5\%) & 0.7 & 0.5 & 0.2 & 0.3 & 5.2 & 5.0 & 0.41 & 0.40 \\
\hline \multicolumn{10}{|c|}{ Effect of the interaction } \\
\hline \multirow{4}{*}{0} & Control & 9.3 & 9.0 & 1.9 & 1.9 & 47.1 & 46.8 & 12.23 & 12.18 \\
\hline & Liquid K & 10.5 & 10.4 & 2.1 & 2.1 & 54.5 & 54.3 & 13.01 & 13.97 \\
\hline & $\mathrm{K}$ borate citrate & 11.4 & 11.2 & 2.3 & 2.2 & 60.8 & 60.6 & 13.67 & 13.64 \\
\hline & NPK- humate & 12.3 & 11.9 & 2.5 & 2.4 & 67.0 & 66.8 & 14.35 & 14.3 \\
\hline \multirow{4}{*}{25} & Control & 11.7 & 11.4 & 2.4 & 2.5 & 57.9 & 57.5 & 14.06 & 13.98 \\
\hline & Liquid K & 12.7 & 12.4 & 2.6 & 2.7 & 65.2 & 64.9 & 14.7 & 14.64 \\
\hline & $\mathrm{K}$ borate citrate & 13.8 & 13.4 & 2.9 & 2.9 & 71.6 & 71.2 & 15.23 & 15.18 \\
\hline & NPK- humate & 14.7 & 14.4 & 3.2 & 3.1 & 77.8 & 77.3 & 15.85 & 15.79 \\
\hline \multirow{4}{*}{50} & Control & 14.1 & 13.8 & 2.7 & 2.8 & 65.7 & 65.2 & 15.36 & 15.3 \\
\hline & Liquid K & 15.1 & 14.7 & 3.1 & 3.2 & 72.5 & 72.0 & 15.94 & 15.88 \\
\hline & $\mathrm{K}$ borate citrate & 15.6 & 15.2 & 3.5 & 3.4 & 78.8 & 78.2 & 16.46 & 16.41 \\
\hline & NPK- humate & 16.3 & 15.7 & 3.7 & 3.6 & 85.1 & 84.6 & 16.98 & 16.93 \\
\hline \multirow{5}{*}{75} & Control & 15.5 & 15 & 3.3 & 3.2 & 72.2 & 72.8 & 16.24 & 16.2 \\
\hline & Liquid K & 16.3 & 15.8 & 3.7 & 3.7 & 79.7 & 79.5 & 16.79 & 16.74 \\
\hline & $\mathrm{K}$ borate citrate & 16.9 & 16.3 & 4.0 & 3.9 & 86.3 & 86.0 & 17.26 & 17.23 \\
\hline & NPK- humate & 17.4 & 16.8 & 4.2 & 4.0 & 92.6 & 92.1 & 17.81 & 17.77 \\
\hline & LSD (5\%) & 0.8 & 0.7 & 0.3 & 0.3 & 6.3 & 5.8 & 0.56 & 0.48 \\
\hline
\end{tabular}

Foliar application of potassium had a significant effect on yield and its components as compared with control treatment in both seasons (Table, 3 ). The highest increases were resulted from foliar spray with NPK-humate. These increases may be ascribed to the role of foliar spray with potassium on increasing photosynthetic activity which accounts much for high translocation of photoassimilates from leaves to the roots (Marschner, 1995). In the same 
respect, Chen and Avaid (1990) added that humic substances have a very pronounced influence on the growth of plant roots and enhance root initiation and increased root growth which known root stimulator. Moreover, Hassan et al. (1992) found that average root weight, root length and yield increased with increasing potassium, nitrogen and phosphorus fertilizer application. Also, the obtained results were in accordance with those obtained by Subrahmanyam and Raju (2000) and El-Tohamy et al. (2011).

The interaction between potassium as a soil or foliar application had significant effects on carrot yield and its components (Table, 3). The highest values were recorded by using $75 \mathrm{~kg} \mathrm{~K}{ }_{2} \mathrm{O} / \mathrm{fad}$. With foliar application of NPK -humate followed by using $75 \mathrm{~kg} \mathrm{~K} \mathrm{~K}_{2} \mathrm{O} / \mathrm{fad}$. with foliar application of potassium borate citrate. These findings were true in both seasons. This might be due to the same treatment to increased size and number of leaves (Table, 2), which led to increasing leaf area and photosynthetic activities. This was reflected in greater root and carrot production per unit area. These results are in good line with those reported El-Bassiony (2006) and El-Bassiony et al. (2010) on onion and sweet pepper.

\section{Chemical composition:}

Increasing potassium fertilization rates significantly increased all chemical composition, i.e., N, P and $\mathrm{K}$ concentrations in leaves and TSS and carotenoids content in roots (Table, 4). N, P and K concentrations in leaves increased gradually with the gradual increase in the dose of potassium. There was no significant effect between 50 and $75 \mathrm{~kg} \mathrm{~K} \mathrm{~K}_{2} \mathrm{O} / \mathrm{fad}$. on $\mathrm{N}$ and $\mathrm{P}$ percentage. Similar results were recorded in both seasons. These results may be due to the role of potassium in plant metabolism and many important regulatory processes in the plant. Also, it could be increased mineral uptake by plants (Marschner, 1995). In this respect, Ali et al. (2003) found that soil application of $\mathrm{K}$ had significant effects on $\mathrm{N}$ content of shoot and had no significant effects on $\mathrm{P}$ and $\mathrm{K}$ contents of shoot. However, Shibairo et al. (1998) and Sanderson and Sanderson (2006) indicated that increasing rates of applied $\mathrm{K}$ linearly increased the $\mathrm{K}$ content of carrot petioles. Also, Kadar (2008) found that potassium uptake was improved by potassium fertilizer application. On the other hand, such results were in agreement with the results reported by Sharangi and Paria (1997), Lyngdoh (2001), Ali et al. (2003) and Anjaiah and Padmaja (2006) who found that total carotenes and total soluble solids increased with increasing levels of potassium.

Results in Table (4) show that, the N, P and K concentrations in leaves as well as TSS and carotenoids content in roots were significantly increased by potassium foliar application as compared with the control treatment. The highest values of chemical composition parameters were obtained when carrot plants sprayed with NPK-humate followed by potassium borate citrate and liquid potassium in both seasons. Increasing N, P and K concentrations in leaves could be attributed to the rapid absorption of these elements by the plant surface, especially the leaves and their translocation within the plant (Marschner, 1995). Similar results were obtained by El-Bassiony (2006) on onion, Fathy and El-Hamady (2007) on cowpea, El-Bassiony et al. (2010) on sweet pepper and El-Tohamy et al. (2011) on carrot. They proposed that potassium foliar application significantly affect $\mathrm{N}, \mathrm{P}$ and $\mathrm{K}$ concentrations in 
plant leaves. However, El-Tohamy et al. (2011) found that the effects were not significant concerning $\mathrm{N}$ and $\mathrm{P}$ contents. In the same regard, El-Tohamy et al. (2011) found that foliar application of K significantly improved the TSS in carrot roots. The improvements in the carotenoids and TSS in roots as a result of NPK-humate foliar application could be attributed to the mode of action of macro nutrients in enhancing the photosynthetic activity and enzymes of carbohydrates transformation.

Table (4): Effect of different potassium levels, potassium foliar application and their interaction on chemical composition of carrot plant in seasons of 2007/08 and 2008/09.

\begin{tabular}{|c|c|c|c|c|c|c|c|c|c|c|}
\hline \multirow[t]{2}{*}{ Treatments } & \multicolumn{2}{|c|}{$\begin{array}{c}\mathrm{N} \% \\
\text { in leaves }\end{array}$} & \multicolumn{2}{|c|}{$\begin{array}{c}\mathrm{P} \% \\
\text { in leaves }\end{array}$} & \multicolumn{2}{|c|}{$\begin{array}{c}\mathrm{K} \% \\
\text { in leaves }\end{array}$} & \multicolumn{2}{|c|}{$\begin{array}{c}\text { TSS } \\
\text { in roots } \\
(\%)\end{array}$} & \multicolumn{2}{|c|}{$\begin{array}{c}\text { Carotenoids } \\
\text { content } \\
\text { (mg/ } 100 \mathrm{~g} \\
\text { root fresh } \\
\text { wt.) }\end{array}$} \\
\hline & $\begin{array}{c}2007 \\
/ 08\end{array}$ & $\begin{array}{c}2008 \\
/ 09\end{array}$ & $\begin{array}{c}2007 \\
/ 08\end{array}$ & $\begin{array}{c}2008 \\
/ 09\end{array}$ & $\begin{array}{c}2007 \\
/ 08\end{array}$ & $\begin{array}{c}2008 \\
/ 09\end{array}$ & $\begin{array}{c}2007 \\
/ 08\end{array}$ & $\begin{array}{c}2008 \\
/ 09\end{array}$ & $\begin{array}{c}2007 \\
/ 08\end{array}$ & $\begin{array}{c}2008 \\
/ 09\end{array}$ \\
\hline \multicolumn{11}{|c|}{ Effect of potassium fertilization rates ( $\mathrm{kg} \mathrm{K}_{2} \mathrm{O} / \mathrm{fed}$.) } \\
\hline 0 & 2.46 & 2.47 & 0.26 & 0.27 & 2.27 & 2.40 & 7.70 & 7.71 & 143 & 139 \\
\hline 25 & 2.71 & 2.73 & 0.29 & 0.29 & 2.70 & 2.73 & 7.87 & 7.86 & 155 & 152 \\
\hline 50 & 2.91 & 2.94 & 0.32 & 0.32 & 3.19 & 3.23 & 8.08 & 8.09 & 168 & 166 \\
\hline 75 & 2.97 & 2.97 & 0.31 & 0.32 & 3.42 & 3.44 & 8.33 & 8.32 & 182 & 180 \\
\hline LSD (5\%) & 0.07 & 0.07 & 0.02 & 0.02 & 0.10 & 0.09 & 0.06 & 0.07 & 3 & 4 \\
\hline \multicolumn{11}{|c|}{ Effect of potassium foliar application } \\
\hline Control & 2.62 & 2.64 & 0.25 & 0.26 & 2.62 & 2.72 & 7.88 & 7.89 & 153 & 149 \\
\hline Liquid K & 2.72 & 2.74 & 0.28 & 0.29 & 2.83 & 2.89 & 7.94 & 7.94 & 161 & 158 \\
\hline $\mathrm{K}$ borate citrate & 2.79 & 2.80 & 0.32 & 0.31 & 2.99 & 3.02 & 8.01 & 8.01 & 165 & 163 \\
\hline NPK- humate & 2.92 & 2.93 & 0.32 & 0.34 & 3.14 & 3.16 & 8.15 & 8.15 & 170 & 168 \\
\hline LSD (5\%) & 0.09 & 0.09 & 0.02 & 0.02 & 0.16 & 0.12 & 0.08 & 0.08 & 5 & 4 \\
\hline \multicolumn{11}{|c|}{ Effect of the interaction } \\
\hline Control & 2.25 & 2.28 & 0.21 & 0.22 & 2.00 & 2.3 & 7.61 & 7.63 & 135 & 129 \\
\hline 0 Liquid K & 2.39 & 2.4 & 0.24 & 0.25 & 2.18 & 2.32 & 7.66 & 7.65 & 142 & 137 \\
\hline $\mathrm{K}$ borate citrate & 2.52 & 2.53 & 0.27 & 0.29 & 2.37 & 2.4 & 7.7 & 7.72 & 146 & 142 \\
\hline NPK- humate & 2.66 & 2.68 & 0.30 & 0.31 & 2.54 & 2.57 & 7.83 & 7.84 & 150 & 148 \\
\hline Control & 2.5 & 2.54 & 0.24 & 0.25 & 2.41 & 2.45 & 7.74 & 7.75 & 146 & 141 \\
\hline Liquid K & 2.65 & 2.69 & 0.27 & 0.29 & 2.62 & 2.65 & 7.81 & 7.8 & 154 & 150 \\
\hline K $\mathrm{K}$ borate citrate & 2.77 & 2.75 & 0.3 & 0.29 & 2.8 & 2.83 & 7.88 & 7.87 & 158 & 155 \\
\hline NPK- humate & 2.9 & 2.92 & 0.33 & 0.34 & 2.98 & 2.99 & 8.04 & 8.03 & 163 & 160 \\
\hline Control & 2.81 & 2.85 & 0.27 & 0.27 & 2.87 & 2.9 & 7.95 & 7.96 & 158 & 155 \\
\hline Liquid K & 2.89 & 2.92 & 0.30 & 0.31 & 3.11 & 3.15 & 8.03 & 8.02 & 166 & 164 \\
\hline $50 \mathrm{~K}$ borate citrate & 2.91 & 2.95 & 0.37 & 0.32 & 3.29 & 3.33 & 8.1 & 8.11 & 171 & 170 \\
\hline NPK- humate & 3.04 & 3.05 & 0.33 & 0.36 & 3.47 & 3.52 & 8.25 & 8.27 & 176 & 176 \\
\hline Control & 2.91 & 2.9 & 0.28 & 0.29 & 3.19 & 3.24 & 8.2 & 8.21 & 171 & 169 \\
\hline${ }_{75}$ Liquid K & 2.94 & 2.94 & 0.31 & 0.32 & 3.41 & 3.45 & 8.27 & 8.27 & 180 & 179 \\
\hline${ }^{15} \mathrm{~K}$ borate citrate & 2.95 & 2.97 & 0.32 & 0.33 & 3.49 & 3.52 & 8.34 & 8.32 & 186 & 184 \\
\hline NPK- humate & 3.08 & 3.08 & 0.33 & 0.33 & 3.57 & 3.56 & 8.49 & 8.47 & 192 & 188 \\
\hline LSD (5\%) & 0.12 & 0.11 & 0.02 & 0.02 & 0.16 & 0.12 & 0.12 & 0.13 & 5 & 6 \\
\hline
\end{tabular}

The interaction between soil and foliar potassium application had a significant effect on N, P and K concentrations in carrot leaves (Table, 4). The highest values were recorded when use $75 \mathrm{Kg} \mathrm{K}_{2} \mathrm{O}$ /fed. as soil fertilizer with potassium foliar application as NPK-humate or potassium borate citrate in both seasons. These results may be due to the role of potassium in plant 
metabolism and many important regulatory processes in the plant. Moreover, potassium and humic substance could be increased mineral uptake by plants (Chen and Avaid, 1990; Marschner, 1995). Also, the interaction effect between potassium fertilization rates and potassium foliar application had a significant effect on TSS and carotenoids content in carrot roots. These results are similar in both seasons. From data presented in Table (4) it could be clearly summarized that the highest values of TSS and carotenoids content were recorded when carrot plants received $75 \quad \mathrm{~K}_{2} \mathrm{O} / \mathrm{fed}$. as fertilization plus NPK-humate as foliar application followed by plants that received $75 \mathrm{~K}_{2} \mathrm{O} / \mathrm{fed}$. plus NPK-humate. These increases may be ascribed to the role of potassium and NPK-humate on increasing photosynthetic activity which accounts much for high translocation of photoassimilates from leaves to the roots.

From the above mentioned results it could be concluded that foliar application of NPK-humate $(3 \mathrm{ml} / \mathrm{L})$ or potassium borate citrate $(3 \mathrm{ml} / \mathrm{L})$ could be successfully used in addition to fertilization application of potassium sulfate with rate of $75 \mathrm{~K}_{2} \mathrm{O}$ /fed. to obtain the highest vegetative growth parameters, total root yield, and significantly enhanced root quality and chemical composition of carrot plants under similar field conditions.

\section{REFERENCES}

Ali, M. A.; M. A. Hossain; M. F. Mondal and A. M. Farooque (2003). Effect of nitrogen and potassium on yield and quality of carrot. Pak. J. Biol. Sci., 6 (18): 1574-1577.

Anjaiah, T. and G. Padmaja (2006). Effect of potassium and farm yard manure on yield and quality of carrot. Journal of Research ANGRAU., 34 (2): 91-93.

Balooch, A.F.; M.A. Balooch and S.M. Qayyum (1993). Influence of phosphorus and potassium fertilizer combination levels with standard dose of nitrogen on the productivity of carrot Daucus carota L. Sarhad J. Agric., 9 (1): 21-25.

Bartaseviciene, B. and J. Pekarskas (2007). The influence of potassium fertilizers on the yield and quality of ecologically cultivated vegetables. Vagos, (74): 7-13.

Chapman, H.D. and P.F. Pratt (1961). Methods of Analysis for Plants and Waters. Publication No. 4034, Agric. Sci. Publication, Univ. of California, Berkeley, California, USA.

Chen, Y. and T. Avaid (1990). Effect of humic substances on plant growth. Pp. 161-186. In: American Society of Agronomy and Soil Science Society of America (eds.), Humic substances in soil and crop science; selected Readings. American Society of Agronomy, Madison, WI.

Chen, Y; C, Clapp and H. Magen (2004). Mechanism of plant growth stimulation by humic substances: The role of organo-iron complexes. Soil Sci. Plant Nutr., 50:1089-1095.

El-Bassiony, A. M. (2006). Effect of potassium fertilization on growth, yield and quality of onion plants. J. Appl. Sci. Res., 2 (10): 780-785. 
El-Bassiony, A.M.; Z. F. Fawzy; E.H. Abd El-Samad and G.S. Riad (2010). Growth, yield and fruit quality of sweet pepper plants (Capsicum annuum L.) as affected by potassium fertilization. Journal of American Science, 6 (12): 722-729.

EL-Bassiouny, R. I.; S.K. EL-Seifi and G. F. Omar (2003). Effect of potassium fertilizer levels on baby carrot growth and storability. J. Agric. Sci. Mansoura Univ., 28 (3): 2063-2097.

El-Tohamy, W.A.; H.M. El-Abagy; M.A. Badr; S.D. Abou-Hussein and Y. I. Helmy (2011). The influence of foliar application of potassium on yield and quality of carrot (Daucus carota L.) plants grown under sandy soil conditions. Aust. J. Basic \& Appl. Sci., 5 (3): 171-174.

Fathy, E. E. and M. M. El-Hamady (2007). Response of cowpea plants (Vigna unguiculata $\mathrm{L}$.) to some biostimulants and organic nutrients during late summer season. J. Product. Dev., 12 (1): 237-250.

Hassan, M. N. M.; Y. Y. Abdel-Ati and M. Farrag (1992). Effect of planting arrangement and NPK fertilizers on carrot under El-Minia conditions. Assiut J. Agri. Sci., 23(4): 121-135.

Hochmuth, G. J.; J. K. Brecht and M. J. Bassett (2006). Fresh-market carrot yield and quality did not respond to potassium fertilization on a sandy soil validated by Mehlich-1 soil test. HortTechnology, 16 (2): 270-276.

Hossain, A. K. M. M.; M. R. Islam; M. S. Bari; M. H. A. Amin and M. A. Kabir. (2009). Effects of mulching and levels of potassium on growth and yield of carrot. Bangladesh Research Publications Journal, 3 (2): 963-970.

Jackson, M.L. (1973). Soil Chemical Analysis. $2^{\text {nd }}$ Ed., Prentice Hall of Indian Private Limited, New Delhi.

Kadar, I. (2008). The effect of fertilization on carrot on calcareous sandy soil. Novenytermeles, 57 (2): 135-147.

Karakurt, Y.; H. Unlu and H. Padem (2009). The influence of foliar and soil fertilization of humic acid on yield and quality of pepper. Acta Agric. Scandinavica, 59 (3): 233-237.

Lyngdoh, G.B.S. (2001). Response of carrot to different levels of nitrogen, phosphorus and potassium. Horticultural Journal, 14 (2): 163-169.

Marschner, H. (1995). Functions of mineral nutrients: micronutrients. In: Mineral Nutrition of Higher Plants. 2nd Ed., Academic Press, London, pp. 313-404.

Page, A.L. (1982). Methods of Soil Analysis. $2^{\text {nd }}$ Ed., Part 1, Soil Sci. Soc. Amer., Madison, Wisc., USA.

Sanderson, K. R. and J. B. Sanderson (2006). Potassium management for carrots in Prince Edward Island. Canadian Journal of Plant, 86(5): 1405-1407.

Sharangi, A.B. and N. C. Paria (1995). Growth, yield and qualitative responses by carrot to varying levels of nitrogen and potassium. Horticultural Journal, 8 (2): 161-164.

Sharangi, A.B. and N.C. Paria (1997). Carotene content of carrot (cv. Pusa Kesar) root as influenced by different levels of nitrogen and potassium. Indian Agriculturist, 41 (3): 193-196. 
Shibairo, S. I.; M. K. Upadhyaya and P. M. A. Toivonen (1998). Potassium nutrition and postharvest moisture loss in carrots (Daucus carota L.). Journal of Horticultural Science and Biotechnology, 73 (6): 862-866.

Snedecor, G.W. and W.G. Cochran (1982). Statistical Methods. $7^{\text {th }}$ Ed., $2^{\text {nd }}$ Printing, lowa State Univ. Press, Ame., USA, 507 PP.

Subrahmanyam, S. V. S. and D. V. R. Raju (2000). Influence of foliar feeding with water soluble specialty fertilizers on three vegetable crops. Advances in Plant Sciences, 13 (2): 589-594.

Umiel, N.; W. H. Gabelman (1971). Analytical procedures for detecting carotenoids of carrot and tomato. J. Am. Soe. Hort, Sei. 96(6): 702704.

Zhang, G.; H. Song-Jiang and X. Song-Hong (2006). Effect of foliar spraying $\mathrm{KH}$ PO on seed production of carrots (Daucus carota L.). China Vegetables, (7): 11-13.

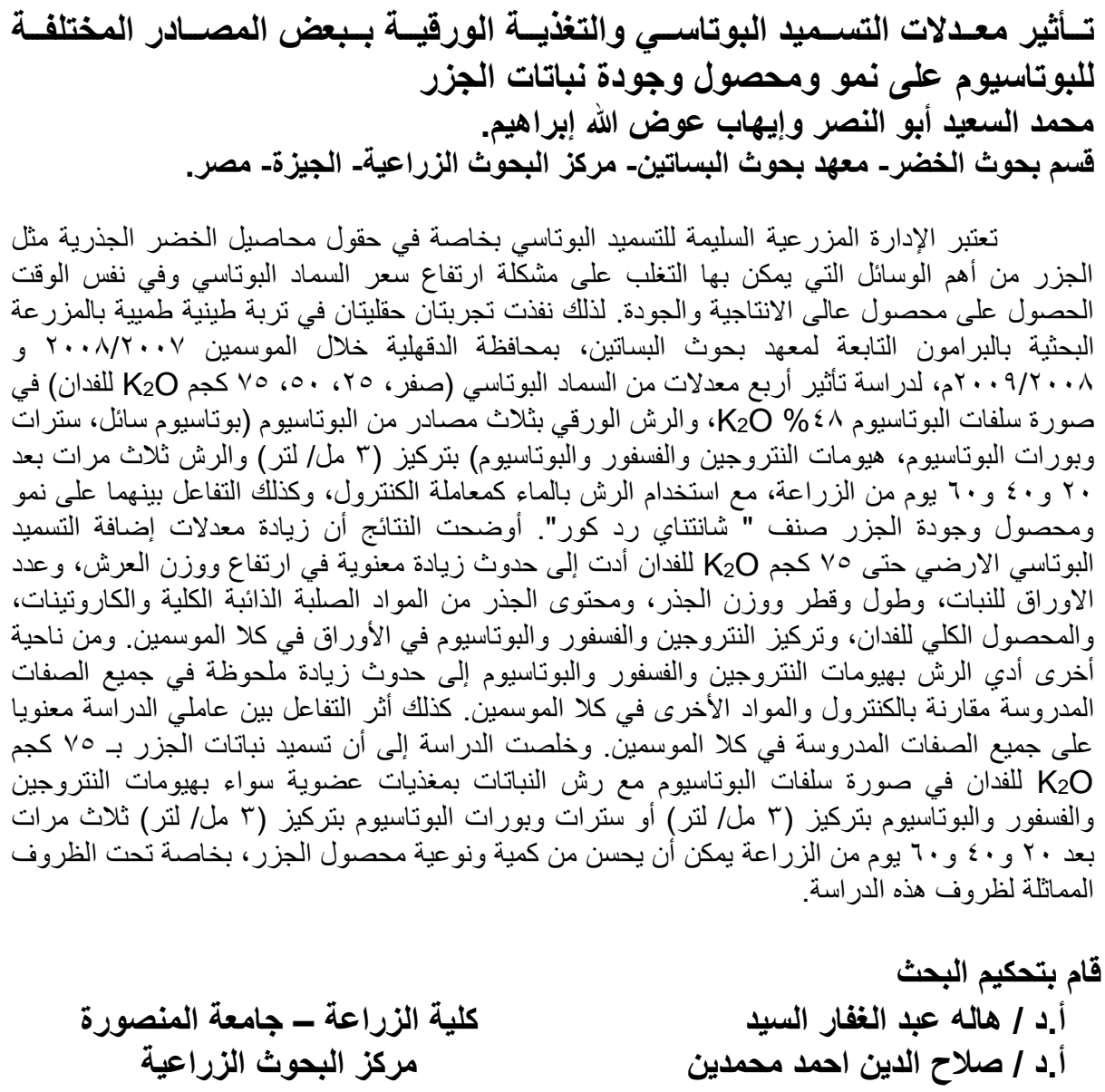

